\title{
ANALISIS TINGKAT KEMISKINAN DAN KETAHANAN PANGAN BERDASARKAN TINGKAT PENGELUARAN KONSUMSI PADA RUMAH TANGGA PEMBUDIDAYA IKAN (Studi Kasus Di Desa Sumur Gintung, Kabupaten Subang, Jawa Barat) Analysis of Poverty Level and Food Security Based on Consumption
Expenditure Level in The Fish Farmer Household
(Case Study in Sumur Gintung Village, Subang District, West Java)
}

\author{
"Lindawati dan Subhechanis Saptanto \\ Balai Besar Penelitian Sosial Ekonomi Kelautan dan Perikanan \\ Gedung Balitbang KP I Lt. 4 \\ Jalan Pasir Putih Nomor 1 Ancol Timur, Jakarta Utara \\ Telp: (021) 64711583 Fax: 64700924 \\ email: nda_1637@yahoo.com \\ Diterima 10 Mei 2013 - Disetujui 3 Nopember 2014
}

\begin{abstract}
ABSTRAK
Tulisan ini bertujuan untuk mengkaji tingkat kemiskinan dan ketahanan pangan berdasarkan tingkat pengeluaran konsumsi pada rumah tangga pembudidaya. Penelitian ini dilakukan di Desa Sumur Gintung, Kabupaten Subang pada tahun 2012. Data yang digunakan dalam penelitian ini adalah data primer dan sekunder. Pemilihan responden dilakukan secara purposive sampling, dengan jumlah responden sebanyak 38 orang. Analisis yang digunakan dalam penelitian ini adalah analisis statistik deskriptif dengan teknik tabulasi silang. Hasil penelitian menunjukkan bahwa pengeluaran konsumsi rumah tangga untuk pangan sebesar $44 \%$ dan non pangan $56 \%$. Sedangkan jika dilihat dari tingkat kemiskinan dengan menggunakan 14 indikator yang dikembangkan oleh BPS menunjukkan bahwa sebanyak $63 \%$ rumah tangga tergolong sejahtera, sedangkan sebesar $37 \%$ kurang sejahtera. Berdasarkan tingkat ketahanan pangan rumah tangga terlihat bahwa sebesar $47 \%$ termasuk dalam kategori rentan pangan sedangkan sisanya 53\% termasuk dalam kategori rawan pangan. Hal ini menunjukkan bahwa rumah tangga pembudidaya apabila dilihat dari tingkat pengeluaran konsumsi dan tingkat kemiskinannya termasuk dalam kategori sejahtera. Sedangkan jika dilihat dari tingkat ketahanan pangannya, rumah tangga pembudidaya masih tergolong rawan pangan meskipun jumlahnya tidak berbeda jauh dengan rumah tangga yang rentan pangan.
\end{abstract}

Kata Kunci: pengeluaran konsumsi, kemiskinan, ketahanan pangan

\begin{abstract}
This paper aimed to analyze poverty level and food security based on consumption expenditure level in the fish farmer households. This research was conducted at Sumur Gintung, a village in Subang District in 2012. Primary and secondary data were used in this study. Thirty eight sample households were collected using purposive sampling method. A statistics descriptive analysis compounded by cross tabulation technique was used in this study. Results showed that percentage of household consumption expenditure is $44 \%$ for food and $56 \%$ for non-food.Meanwhile, by using 14 indicators of BPS show that for $63 \%$ of households could be classified as prosperous households, while $37 \%$ were less prosperous households. The level of household food security showed that $47 \%$ were food vulnerable category and 53\% were food insecurity category. It indicated that based on level of consumption expenditure and poverty level, fish farmers were included in the prosperous category. While based on level of food security, fish farmers were classified as food insecured although it did not have significant value with food vulnerability.
\end{abstract}

Keywords: consumption expenditure, poverty and food security 


\section{PENDAHULUAN}

Pengukuran kesejahteraan rumah tangga atau keluarga salah satunya dapat dilihat dari indikator pengeluaran rumah tangga. Suatu rumah tangga diindikasikan berpenghasilan rendah apabila pengeluaran rumah tangga untuk makanan terhadap total pengeluaran lebih besar dibandingkan dengan pengeluaran bukan makanan. Semakin kecil persentase pengeluaran makanan terhadap total pengeluaran rumah tangga, makin sejahtera rumah tangga tersebut (Ilham \& Sinaga, 2004). Tingkat pengeluaran rumah tangga terdiri dari pengeluaran untuk makanan dan bukan makanan, dimana kebutuhan akan kedua pengeluaran tersebut berbeda. Pada saat pendapatan yang diperoleh terbatas maka rumah tangga akan lebih mementingkan kebutuhan konsumsi makanan, sehingga pada kelompok masyarakat berpendapatan rendah akan terlihat bahwa sebagaian besar pendapatannya digunakan untuk membeli makanan. Pada saat pendapatan meningkat maka akan terjadi pergeseran pola pengeluaran yaitu penurunan porsi pendapatan yang dibelanjakan untuk makanan dan peningkatan porsi pendapatan yang dibelanjakan untuk bukan makanan (BPS, 2011).

Pengeluaran rumah tangga terhadap konsumsi sangat erat kaitannya dengan pendapatan yang diperoleh rumah tangga tersebut. Pendapatan yang diperoleh dalam suatu rumah tangga mencerminkan tingkat kesejahteraan atau kemiskinan rumah tangga tersebut. Menurut Badan Pusat Statistik (2010), kemiskinan merupakan kondisi ketidakmampuan seseorang dalam memenuhi kebutuhan dasar baik makanan maupun non makanan yang diukur dari sisi pengeluaran. Sedangkan menurut Irawan (2000), kemiskinan merupakan kondisi ketidaksejahteraan keluarga dan dipandang sebagai ketidakmampuan untuk memenuhi kebutuhan dasar makanan dan non makanan yang diukur dengan menggunakan garis kemiskinan. Garis kemiskinan sangat sensitif terhadap faktor harga, penentuan standar minimum kebutuhan dasar, pemilihan jenis paket komoditi, serta karakteristik wilayah.

Berdasarkan data yang dikeluarkan oleh BPS, bahwa pada September 2013 jumlah penduduk miskin di Indonesia mencapai 28,55 juta orang (11,47 persen) dari jumlah penduduk yang terdistribusi di daerah perkotaan sebanyak $8,52 \%$ dan di daerah pedesaan sebanyak 14,42 persen. Menurut Sukiyono et al. (2008), tingginya tingkat kemiskinan masyarakat di pedesaan dapat dijadikan indikasi menurunnya tingkat kesejahteraan yang berarti pula menurunnya tingkat atau berubahnya pola konsumsi masyarakat. Adapun permasalahan mendasar kualitas masyarakat kelautan dan perikanan khususnya pembudidaya ikan yang menyebabkan kemiskinan antara lain kurangnya akses permodalan, pasar dan teknologi serta lemahnya kelembagaan kelompok usaha kelautan dan perikanan termasuk kelompok pembudidaya ikan (pokdakan).

Menurut Undang-Undang No.18 Tahun 2012, ketahanan pangan adalah kondisi terpenuhinya pangan bagi negara sampai dengan perseorangan yang tercermin dari tersedianya pangan yang cukup, baik jumlah maupun mutunya, aman, beragam, bergizi, merata, dan terjangkau serta tidak bertentangan dengan agama, keyakinan, dan budaya masyarakat, untuk dapat hidup sehat, aktif, dan produktif secara berkelanjutan. Ketahanan pangan merupakan sistem yang terdiri atas subsistem ketersediaan dan distribusi pangan serta subsistem konsumsi.

Ketersediaan dan distribusi memfasilitasi pasokan pangan yang stabil dan merata keseluruh wilayah, sedangkan subsistem konsumsi memungkinkan setiap rumah tangga memperoleh pangan yang cukup dan memanfaatkannya secara bertanggungjawab untuk memenuhi kebutuhan gizi seluruh anggotanya (Suryana, 2004). Berdasarkan paparan, penulisan ini bertujuan untuk mengkaji tingkat pengeluaran rumah tangga dalam kaitannya dengan ketahanan pangan dan tingkat kemiskinan pada rumah tangga pembudidaya.

\section{METODOLOGI}

\section{Lokasi dan Waktu Penelitian}

Lokasi yang dipilih dalam penelitian ini adalah Desa Sumur Gintung, Kecamatan Pagaden Barat, Kabupaten Subang, dengan pertimbangan bahwa lokasi tersebut merupakan salah satu daerah penghasil benih untuk usaha budidaya ikan mas. Lokasi ini merupakan salah satu lokasi penelitian Panel Kelautan dan Perikanan Nasional (PANELKANAS) yang merupakan representasi dari tipologi budidaya. Waktu penelitian dilakukan pada bulan Juli 2012.

\section{Metode Pengumpulan Data}

Data yang digunakan dalam penelitian ini menggunakan data primer dan sekunder. Data 
sekunder diperoleh dari Dinas Perikanan dan Kelautan, Badan Ketahanan Pangan dan Badan Pusat Statistik di Kabupaten Subang. Data yang dikumpulkan berupa gambaran umum dan kondisi masyarakat di Subang, data produksi hasil perikanan dan data ketahanan pangan. Data primer dikumpulkan dengan menggunakan kuesioner terstruktur terkait dengan identitas dan karakteristik responden, mata pencaharian, tingkat pendapatan, ketahanan pangan dan kemiskinan serta pengeluaran konsumsi rumah tangga. Metode pengumpulan data menggunakan purposive sampling dengan pertimbangan bahwa responden yang dipilih yang melakukan kegiatan usaha budidaya ikan mas (baik pembenihan maupun pendederan). Jumlah responden yang dikumpulkan dalam penelitian ini berjumlah 38 orang.

\section{Metode Analisis Data}

Metode analisis data yang digunakan dalam penelitian ini adalah analisis statistik deskriptif dalam bentuk tabulasi silang. Analisis ini digunakan dalam rangka mengintreprestasikan tingkat pengeluaran konsumsi, ketahanan pangan dan tingkat kemiskinan rumah tangga pembudidaya ikan mas di Desa Sumur Gintung, Kabupaten Subang. Pengeluaran konsumsi dianalisis dengan menghitung pengeluaran pangan dengan non pangan pada tingkat rumah tangga.

Analisis ketahanan pangan dilakukan untuk mengetahui status ketahanan pangan (kerawanan pangan) rumah tangga. Tingkat ketahanan pangan diukur dengan indikator klasifikasi silang antara pangsa pengeluaran pangan dan kecukupan energi (Maxwell et al., 2000 dalam Purwaningsih et al., 2010).
Pangsa pengeluaran pangan mengukur ketahanan pangan dari aspek ekonomi, sedangkan pemenuhan kecukupan konsumsi pangan dalam satuan energi mengukur ketahanan pangan dari aspek gizi (Saliem et al., 2008). Tingkat ketahanan pangan berdasarkan indikator tersebut dikelompokkan menjadi 4 (empat) kategori, yaitu (1) Tahan pangan: Proporsi pengeluaran pangan ( $\leq 60 \%$ ), konsumsi cukup (> $80 \%$ kecukupan energi); (2) Rentan pangan : Proporsi pengeluaran pangan ( $>60 \%$ ), konsumsi cukup ( $>80 \%$ kecukupan energi); (3) Kurang pangan : Proporsi pengeluaran pangan $(\leq 60 \%)$, konsumsi kurang ( $\leq 80 \%$ Angka Kecukupan Gizi / AKG); (4) Rawan pangan: Proporsi pengeluaran pangan (> 60\%), konsumsi kurang ( $\leq 80 \%$ kecukupan energi), seperti terlihat pada Tabel 1. Angka kecukupan gizi (AKG) yang digunakan dalam penulisan ini mengacu kepada Widyakarya Nasional Pangan dan Gizi (WNPKG) $X$ tahun 2012, yaitu $2.150 \mathrm{kkal}$ dan 57 gram protein (Kartono et al., 2012 dalam BPS, 2013).

Sedangkan untuk melihat tingkat kemiskinan pada rumah tangga pembudidaya diukur melalui pendekatan karakteristik kemiskinan dengan menggunakan 14 indikator yang dikembangkan oleh Badan Pusat Statistik (BPS). Keempat belas indikator tersebut adalah luasan rumah, jenis lantai, jenis dinding, fasilitas toilet, sumber penerangan, sumber air minum, jenis bahan bakar, konsumsi daging, susu, ayam, ikan, belanja pakaian, frekuensi makan perhari, kemampuan berobat, pendapatan rumah tangga, pendidikan kepala keluarga dan tabungan / kepemilikan barang berharga (BPS, 2005). Pada masing-masing indikator tersebut diberikan bobot nilai antara nilai 0 sampai dengan 4 .

Tabel 1. Pengukuran Tingkat Ketahanan Pangan Rumah Tangga.

Table 1. Measurement of Household Food Security Level.

\begin{tabular}{|c|c|c|}
\hline \multirow[b]{2}{*}{$\begin{array}{l}\text { Konsumsi Energi/ } \\
\text { Energy Consumption) }\end{array}$} & \multicolumn{2}{|c|}{ Pangsa Pengeluaran Pangan/ Food Expenditure Share } \\
\hline & $\begin{array}{c}\text { Rendah/ Low ( } \leq 60 \% \\
\text { Pengeluaran Total/ Total } \\
\text { Expenditure) }\end{array}$ & $\begin{array}{c}\text { Tinggi/ High } \\
\text { ( }>60 \% \text { Pengeluaran Total } / \\
\text { Total Expenditure) }\end{array}$ \\
\hline $\begin{array}{l}\text { Cukup / Adequate ( > 80\% } \\
\text { kecukupan energi/ Energy } \\
\text { sufficiency) }\end{array}$ & $\begin{array}{l}\text { Tahan Pangan/ } \\
\text { Food Secure }\end{array}$ & $\begin{array}{l}\text { Rentan Pangan/ } \\
\text { Food Vulnerable }\end{array}$ \\
\hline $\begin{array}{l}\text { Kurang/ Inadequate ( } \leq 80 \% \\
\text { kecukupan energi/ Energy } \\
\text { sufficiency) }\end{array}$ & $\begin{array}{l}\text { Kurang Pangan/ } \\
\text { Questionable }\end{array}$ & $\begin{array}{l}\text { Rawan Pangan/ } \\
\text { Food Insecure }\end{array}$ \\
\hline
\end{tabular}

Sumber : Johnson \& Toole (1991) dalam Maxwell et al. (2000)/

Source: Johnson \& Toole (1991) in Maxwell et al. (2000) 
Tabel 2. Rentang Nilai dan Tingkat Kemiskinan Masyarakat Berdasarkan Pendekatan Karakteristik RumahTangga.

Table 2. Ranged Values and Community Poverty Level Based on Household Characteristics.

\begin{tabular}{ccl}
$\begin{array}{c}\text { Kelas/ } \\
\text { Class }\end{array}$ & $\begin{array}{c}\text { Rentang Nilai/ } \\
\text { Range of Value }\end{array}$ & \multicolumn{1}{c}{$\begin{array}{c}\text { Tingkat Kemiskinan/ } \\
\text { Poverty Level }\end{array}$} \\
I & $0.00-0.25$ & Sangat Miskin/ Very Poor \\
II & $0.26-0.50$ & Miskin/ Poor \\
III & $0.51-0.75$ & Kurang Sejahtera/ Less Prosperous \\
IV & $0.76-1.00$ & Sejahtera/ Prosperous \\
\hline
\end{tabular}

Sumber: Badan Pusat Statistik, 2005 / Sources : Central Agency of Statistic, 2005

Berdasarkan hasil pembobotan tersebut, akan diperoleh nilai bobot total antara 0 hingga 1. Nilai tersebut menunjukkan kriteria tingkat kemiskinan rumah tangga yang dibagi empat kategori, yaitu sangat miskin, miskin, kurang sejahtera dan sejahtera (Tabel 1).

\section{HASIL DAN PEMBAHASAN}

\section{Karakteristik Rumah Tangga Responden}

Karakteristik rumah tangga sangat penting dalam memberikan gambaran tentang kondisi aktual dalam masyarakat. Karakteristik responden yang diamati dalam penelitian ini meliputi umur, tingkat pendidikan dan jumlah anggota keluarga. Umur merupakan salah satu faktor yang berpengaruh terhadap aktivitas usaha, dengan umur semakin tua akan semakin lambat dalam menerima inovasi baru (Fauzi, 2007). Pembudidaya yang berada pada umur produktif diharapkan dapat bekerja dengan optimal untuk mendapatkan hasil yang maksimal. Selain itu, umur juga berpengaruh terhadap pemenuhan kebutuhan akan gizi. Kebutuhan akan gizi tiap individu berbeda, semakin bertambahnya umur maka akan menuntut pemenuhan gizi yang berbeda juga. Menurut Kamaludin (1994), bahwa umur digolongkan dalam tiga kategori yaitu (1) umur tidak produktif ( $<25$ dan $>65$ tahun), (2) umur produktif ( $>45-65$ tahun) dan (3) umur sangat produktif ( $25-45$ tahun). Berdasarkan hasil survey diketahui bahwa kisaran umur responden antara 27 tahun sampai dengan 68 tahun. Hasil perhitungan umur responden tersebut didominasi pada umur sangat produktif ( 25 - 45 tahun) yaitu sebesar $58 \%$.

Tingkat pendidikan juga merupakan salah satu faktor keberhasilan seseorang dalam melakukan suatu usaha. Hal ini dikarenakan tingkat pendidikan akan menentukan seseorang dalam berfikir, bersikap dan bertindak dalam mengelola usahanya, seperti kemampuan dalam menyerap suatu inovasi baru. Chamdi (2003) menyatakan bahwa dengan tingkat pendidikan akan menambah pengetahuan dan keterampilan sehingga akan meningkatkan produktivitas kerja dan akan menentukan keberhasilan usaha budidaya. Hasil survey menunjukkan bahwa tingkat pendidikan pembudidaya didominasi oleh tamatan SLTA (umum/kejuruan) sebesar 32\%, dilanjutkan dengan tamatan SD (26\%), tamatan SLTP (21\%), tidak sekolah/belum tamat SD $(18 \%)$ dan tamatan perguruan tinggi/universitas (3\%). Hal ini menunjukkan bahwa tingkat pendidikan yang ditempuh pembudidaya cukup baik, karena sebagian besar pembudidaya tamatan SLTA (umum/kejuruan). Tingkat pendidikan ini menjadi faktor yang mempengaruhi responden dalam mengelola usahanya.

Jumlah anggota rumah tangga akan berpengaruh terhadap besarnya tanggungan keluarga. Hasil survey menunjukkan bahwa sebagian besar $(61 \%)$ anggota rumah tangga responden berjumlah $3-4$ orang yang terdiri dari ayah, ibu dan anak (keluarga inti). Selain itu juga besar kecilnya anggota rumah tangga akan mempengaruhi tingkat konsumsi dan pengeluaran rumah tangga, semakin banyak anggota rumah tangga maka akan semakin meningkat juga jumlah barang yang diminta.

\section{Pengeluaran Rumah Tangga Pembudidaya}

Struktur pengeluaran rumah tangga merupakan salah satu indikator tingkat kesejahteraan rumah tangga. Rumah tangga dengan pangsa pengeluaran pangan tinggi menunjukkan tingkat kesejahteraan yang relatif lebih rendah dibandingkan rumah tangga dengan proporsi pengeluaran untuk pangan rendah. 
Tabel 3. Karakteristik Responden pada Usaha Budidaya Ikan Mas di Desa Sumur Gintung, Kabupaten Subang, Tahun 2012.

Table 3. Respondent Characteristics on Carp Culture at Sumur Gintung, Subang District, 2012.

\begin{tabular}{|c|c|c|c|}
\hline No & Uraian/ Description & $\begin{array}{c}\text { Jumlah/Numbers } \\
\text { (orang/people) }\end{array}$ & $\begin{array}{c}\text { Persentase/ } \\
\text { Percentace (\%) }\end{array}$ \\
\hline \multirow[t]{4}{*}{1} & Usial Ages & & \\
\hline & a. $<25$ Tahun / under 25 years old & 0 & - \\
\hline & b. 25 - 45 Tahun / 25 - 45 years old & 22 & 58 \\
\hline & c. $>45$ / over 45 years old & 16 & 42 \\
\hline \multirow[t]{3}{*}{2} & $\begin{array}{l}\text { Tingkat pendidikan/ Education level } \\
\text { a. Tidak Sekolah/ Belum Tamat SD/ No } \\
\text { education/ Unfinished elementary school }\end{array}$ & 7 & 18 \\
\hline & b. SD/ Elementary school & 10 & 26 \\
\hline & $\begin{array}{l}\text { c. SLTP/ Junior high school } \\
\text { d. SLTA (umum/kejuruan)/ Senior high school } \\
\text { (general/vocational) }\end{array}$ & $\begin{array}{r}8 \\
12\end{array}$ & $\begin{array}{l}21 \\
32\end{array}$ \\
\hline \multirow[t]{4}{*}{3} & $\begin{array}{l}\text { e. Perguruan Tinggi/ College } \\
\text { Jumlah Anggota Rumah Tangga/ } \\
\text { Number of Household Members }\end{array}$ & 1 & 3 \\
\hline & a. 1 - 2 orang/ 1 - 2 people & 7 & 18 \\
\hline & b. 3 - 4 orang/ $3-4$ people & 23 & 61 \\
\hline & 4 orang/ over 4 people & 8 & 21 \\
\hline
\end{tabular}

Sumber : Data Primer Diolah, 2012/Sources : Primary Data Processed, 2012

Semakin tinggi pangsa pengeluaran pangan, berarti semakin kurang sejahtera rumah tangga yang bersangkutan. Sebaliknya, semakin kecil pangsa pengeluaran pangan maka rumah tangga tersebut semakin sejahtera.

Pengeluaran rumah tangga merupakan biaya yang dikeluarkan untuk konsumsi semua anggota rumah tangga. Konsumsi rumah tangga digolongkan menjadi dua yaitu konsumsi pangan dan non pangan. Pengeluaran untuk konsumsi rumah tangga dalam penelitian ini merujuk pada BPS, dimana konsumsi pangan dikelompokkan menjadi 14 kelompok besar, yaitu padi-padian, umbi-umbian, ikan, daging, telur dan susu, sayursayuran, kacang-kacangan, buah-buahan, minyak dan lemak, bahan minuman, bumbu-bumbuan, konsumsi lainnya, makanan dan minuman jadi, serta tembakau dan sirih. Sedangkan konsumsi non pangan dibagi menjadi 5 (lima) kelompok, yaitu perumahan dan fasilitas rumah tangga, aneka barang dan jasa, pakaian, alas kaki dan tutup kepala, pajak dan asuransi serta keperluan pesta dan upacara.
Berdasarkan hasil analisis yang telah dilakukan, pangsa pengeluaran rumah tangga untuk pangan dan non pangan tidak terlalu jauh berbeda, meskipun pengeluaran untuk non pangan lebih besar dibandingkan dengan pengeluaran pangan. Distribusi pengeluaran pangan sebesar Rp. 411.817 / kapita per bulan (44,22\%), sedangkan untuk pengeluaran non pangan sebesar Rp. 519.398 / kapita per bulan (55,78\%). Berdasarkan perbandingan besarnya pangsa pengeluaran pangan dan non pangan, menunjukkan bahwa rumah tangga perikanan budidaya di Desa Sumur Gintung dapat dikategorikan dalam rumah tangga sejahtera.

Data BPS pada tahun 2011 menunjukkan bahwa rata-rata pangsa pengeluaran pangan rumah tangga untuk perkotaan dan perdesaan di Provinsi Jawa Barat adalah sebesar Rp. 297.590/ kapita per bulan dan pangsa pengeluaran non pangan sebesar Rp. 311.118 / kapita per bulan. Berdasarkan hal ini diketahui bahwa pangsa pengeluaran rumah tangga pembudidaya di Desa Sumur Gintung memiliki tingkat 
kesejahteraan yang lebih tinggi jika dibandingkan rumah tangga pada sektor pekerjaan lainnya di Provinsi Jawa Barat.

Secara agregat diketahui bahwa pengeluaran pangan dominan di Desa Sumur Gintung, Kabupaten Subang adalah untuk kelompok tembakau dan sirih yaitu sebesar Rp. 76.917 / kapita per bulan (82,6 \%). Hal ini tidak terlepas dari kebiasaan merokok pada sebagian besar anggota rumah tangga. Untuk pengeluaran pangan sumber karbohidrat atau padi-padian sebesar Rp. 51.857 / kapita per bulan. Pengeluaran untuk kelompok tembakau lebih besar dari pengeluaran untuk sumber karbohidrat (kelompok padi-padian). Menurut hasil penelitian yang dilakukan oleh Purwantini dan Ariani (2008), padi merupakan sumber karbohidrat utama dan merupakan pangan pokok nasional. Akan tetapi, pada kenyataannya terjadi pergeseran untuk konsumsi kelompok padi-

Tabel 4. Pengeluaran Konsumsi Rumah Tangga Pembudidaya Ikan Mas Di Desa Sumur Gintung, Kabupaten Subang, Tahun 2012.

Table 4. Consumption Expenditure of Fish Farmers Household in Sumur Gintung, Subang District, 2012.

\begin{tabular}{|c|c|c|c|}
\hline No. & $\begin{array}{l}\text { Kelompok Makanan } \\
\text { (Food Group) }\end{array}$ & $\begin{array}{l}\text { Nilai (Rp/kapita/bln) } \\
\text { Value (Rp/Capita/Month) }\end{array}$ & $\begin{array}{c}\text { Persentase/ } \\
\text { Percentages (\%) }\end{array}$ \\
\hline 1. & Padi-padian / Cereals & 51,857 & 5.57 \\
\hline 2. & Umbi-umbian / Tubers & - & 0.00 \\
\hline 3. & Ikan / fish & 35,514 & 3.81 \\
\hline 4. & Daging / Meat & 35,794 & 3.84 \\
\hline 5. & Telur dan susu / Eggs and Milk & 38,133 & 4.09 \\
\hline 6. & Sayur-sayuran / Vegetables & 25,122 & 2.70 \\
\hline 7. & Kacang-kacangan / Legumes & 14,027 & 1.51 \\
\hline 8. & Buah-Buahan / Fruits & 23,192 & 2.49 \\
\hline 9. & Minyak dan Lemak / Oil And Fats & 13,425 & 1.44 \\
\hline 10. & Bahan Minuman / Beverages & 30,308 & 3.25 \\
\hline 11. & Bumbu-Bumbuan / Spices & 5,992 & 0.64 \\
\hline 12. & Konsumsi Lainnya / Miscellaneous & 18,923 & 2.03 \\
\hline 13. & $\begin{array}{l}\text { Makanan dan Minuman Jadi / Prepared } \\
\text { Food and Beverages }\end{array}$ & 42,613 & 4.58 \\
\hline \multirow[t]{2}{*}{14.} & $\begin{array}{l}\text { Tembakau dan Sirih / Tobacco and } \\
\text { Betel }\end{array}$ & 76,917 & 8.26 \\
\hline & Jumlah Makanan / Total Food & 411,817 & 44.22 \\
\hline 15. & $\begin{array}{l}\text { Perumahan dan Fasilitas Rumah } \\
\text { Tangga / Housing and Household } \\
\text { Facility }\end{array}$ & 259,417 & 27.86 \\
\hline 16. & $\begin{array}{l}\text { Aneka Barang Dan Jasa / Goods and } \\
\text { Services }\end{array}$ & 140,633 & 15.10 \\
\hline 17. & $\begin{array}{l}\text { Pakaian, Alas Kaki dan Tutup Kepala / } \\
\text { Clothing, Footwear and Headgear }\end{array}$ & 24,304 & 2.61 \\
\hline 19. & $\begin{array}{l}\text { Pajak dan Asuransi / Taxes and } \\
\text { Insurance }\end{array}$ & 13,851 & 1.49 \\
\hline \multirow[t]{3}{*}{20.} & $\begin{array}{l}\text { Keperluan Pesta dan Upacara / Parties } \\
\text { and Ceremonies }\end{array}$ & 81,193 & 8.72 \\
\hline & $\begin{array}{l}\text { Jumlah Bukan Makanan I } \\
\text { Total Non Food }\end{array}$ & 519,398 & 55.78 \\
\hline & Jumlah/Total & 931,215 & 100 \\
\hline
\end{tabular}

Sumber : Data Primer Diolah, 2012/ Sources : Primary Data Processed, 2012 
padian (dalam hal ini beras) pada rumah tangga pembudidaya. Kondisi ini diduga karena adanya pergeseran selera konsumsi dan preferensi konsumen yang berbeda pada setiap wilayah. Pergeseran tersebut menyebabkan rumah tangga mengalihkan pengeluaran konsumsinya untuk kelompok makanan dan minuman jadi, yaitu sebesar Rp. 42.613 / kapita per bulan atau 4,58 $\%$ dari total pengeluaran konsumsi (meskipun nilainya masih lebih rendah untuk pengeluaran kelompok padi-padian). Berdasarkan informasi yang diperoleh, diketahui bahwa sebagian besar rumah tangga mempunyai sawah sendiri yang tujuannya untuk memenuhi kebutuhan keluarga sehari-hari, sehingga sebagian besar responden tidak mengeluarkan biaya untuk pembelian beras karena berasal dari hasil sawah sendiri.

Pengeluaran pangsa pangan terbesar selanjutnya adalah untuk konsumsi pangan hewani, yang diperoleh dari ikan, daging, telur dan susu, yaitu masing-masing sebesar Rp. 35.514 / kapita per bulan (3,81\%), Rp. 35.794 / kapita per bulan (3,84\%) dan Rp. 38.133 / kapita per bulan $(4,09 \%)$. Jenis pangan ini biasanya relatif mahal dibandingkan dengan harga pangan lainnya. Walaupun dalam jumlah relatif kecil yang dikonsumsi tetapi karena harganya cukup mahal sehingga nilai pengeluaran cukup besar.

Pengeluaran non pangan secara agregat memliki persentase yang lebih besar dibandingkan pengeluaran pangan. Pengeluaran non pangan yang paling besar adalah untuk kelompok perumahan dan fasilitas rumah tinggal, serta kelompok aneka barang dan jasa yang mencapai Rp. 259.417 / kapita per bulan $(27,86 \%)$ dan Rp. 140.633 / kapita per bulan $(15,10 \%)$. Kelompok perumahan dan fasilitas rumah, pengeluaran terbesar dari rekening listrik, pembelian pulsa handphone dan pembelian gas (LPG) untuk memasak. Pengeluaran untuk kelompok aneka barang dan jasa yang paling besar adalah perlengkapan mandi dan cuci, biaya pendidikan (iuran sekolah, ongkos/transportasi, uang saku, serta pembelian buku), serta pembelian bensin (baik untuk motor atau mobil, yang digunakan untuk kegiatan sehari-hari).

\section{Tingkat Konsumsi Energi dan Protein}

Tingkat konsumsi energi dan protein merupakan cerminan dari kualitas dan kuantitas pangan yang dikonsumsi oleh individu atau rumah tangga. Pangan pokok biasanya merupakan sumber karbohidrat sekaligus sebagai sumber energi. Kebutuhan minimum seseorang bisa hidup layak dan sehat yaitu dengan terpenuhinya energi sebanyak $2.150 \mathrm{kkal} / \mathrm{kapita} / \mathrm{hari}$ dan protein sebanyak 57 gram/kapita/hari (Kartono et al., 2012 dalam BPS, 2013).

Berdasarkan Tabel 4, diketahui bahwa rumah tangga pembudidaya dapat memenuhi kebutuhan minimum energi dan protein. Rata-rata tingkat konsumsi energi dan proteinnya adalah sebesar 2.400,25 kkal/kapita/hari dan 73,47 gram/ kapita/hari. Sumber kalori yang berasal dari padipadian mencapai 1.258,53 kkal/kapita/hari dan sumber protein yang berasal dari ikan mencapai 14,06 gram/kapita/hari. Hal ini menunjukkan bahwa konsumsi padi-padian (dalam hal ini beras) sebagai sumber energi sekaligus sumber protein yang cukup tinggi.

\section{Ketahanan Pangan Rumah Tangga}

Komponen yang digunakan untuk menentukan ketahanan pangan rumah tangga dapat dilihat dari proporsi pengeluaran pangan dan konsumsi energi. Berdasarkan Tabel 5 diketahui bahwa sebaran ketahanan pangan rumah tangga berada pada kategori rentan pangan dan rawan pangan dengan besaran yang tidak jauh berbeda. Hasil kajian menunjukkan sebesar $52,63 \%$ rumah tangga termasuk dalam kategori rawan pangan, sedangkan sebesar $47,37 \%$ rumah tangga termasuk dalam kategori rentan pangan. Seperti yang diungkapkan oleh Ariani dan Rachman (2003), bahwa dengan memperhatikan indikator pangsa pengeluaran pangan sebagai proksi indikator ekonomi, maka rumah tangga yang berpendapatan rendah adalah rumah tangga yang termasuk kategori rentan pangan dan rawan pangan.

Rumah tangga rentan pangan adalah rumah tangga yang mempunyai proporsi pengeluaran pangan yang tinggi (lebih dari $60 \%$ ) namun cukup mengkonsumsi energi. Pangsa pengeluaran pangan tinggi berarti lebih dari 60 persen bagian pendapatan dibelanjakan untuk pangan. Kondisi ini mengindikasikan rendahnya pendapatan yang diterima oleh kelompok rumah tangga tersebut. Namun demikian, dengan keterbatasan pendapatan yang dimiliki, rumah tangga rentan pangan dapat mengalokasikan pengeluaran pangannya sehingga dapat memenuhi kecukupan energi. Pada kelompok rumah tangga ini, pendapatan merupakan faktor utama untuk mencapai ketahanan pangan. Hasil penelitian dari Ariani dan Rachman (2003) menunjukkan bahwa rumah tangga yang termasuk dalam kategori rentan pangan mengindikasikan bahwa jenis 
pangan yang dikonsumsi sebagian besar berasal dari pangan sumber energi yang harganya lebih murah. Karena disinyalir pangan yang dikonsumsi kurang beragam dan dominan karbohidrat, maka kualitas pangan juga termasuk rendah (kurang bergizi), tidak sesuai anjuran gizi untuk mencapai tubuh yang sehat. Sehingga untuk mencapai ketahanan pangan diperlukan peningkatan akses terhadap pangan melalui peningkatan pendapatan diikuti dengan peningkatan pengetahuan pangan dan gizi. Seperti diungkapkan oleh Baliwati (2001) bahwa pendapatan dapat dijadikan penciri atau indikator ketahanan pangan rumah tangga.
Rumah tangga rawan pangan adalah rumah tangga yang mempunyai pangsa pengeluaran pangan yang tinggi dan kurang mengkonsumsi energi. Pangsa pengeluaran pangan tinggi berarti lebih dari $60 \%$ bagian pendapatan dibelanjakan untuk pangan. Kondisi ini mengindikasikan rendahnya pendapatan yang diterima oleh kelompok rumah tangga tersebut. Rendahnya pendapatan yang dimiliki menyebabkan alokasi untuk pengeluaran pangan tidak dapat memenuhi kecukupan energinya. Sehingga pendapatan dan pengetahuan gizi merupakan faktor yang menentukan kelompok rumah tangga ini untuk

Tabel 5. Tingkat Konsumsi Energi dan Protein pada Rumah Tangga Pembudidaya Ikan Mas di Desa Sumur Gintung, Kabupaten Subang, Tahun 2012.

Table 5. Consumption Level of Fish Farmer Household Based on Energy and Protein Consumption at Sumur Gintung Village, Subang, 2012.

\begin{tabular}{|c|c|c|c|}
\hline \multirow{2}{*}{ No. } & \multirow{2}{*}{$\begin{array}{l}\text { Kelompok Makanan } \\
\text { (Food Group) }\end{array}$} & \multicolumn{2}{|c|}{$\begin{array}{c}\text { Konsumsi Kalori dan Protein } \\
\text { (Consumption of Calorie and Protein) }\end{array}$} \\
\hline & & $\begin{array}{l}\text { Kalori/ Calorie } \\
\text { (Kkal/Cap/day) }\end{array}$ & $\begin{array}{l}\text { Protein/ Protein } \\
\text { (Gram/Cap/day) }\end{array}$ \\
\hline 1. & Padi-padian / Cereals & $1,258.53$ & 29.45 \\
\hline 2. & Umbi-umbian / Tubers & - & - \\
\hline 3. & Ikan / Fish & 93.77 & 14.06 \\
\hline 4. & Daging / Meat & 116.62 & 7.10 \\
\hline 5. & Telur dan susu / Eggs and Milk & 140.57 & 6.10 \\
\hline 6. & Sayur-sayuran / Vegetables & 30.43 & 1.53 \\
\hline 7. & Kacang-kacangan / Legumes & 68.96 & 6.92 \\
\hline 8. & Buah-buahan / Fruits & 49.09 & 0.60 \\
\hline 9. & Minyak dan lemak / Oil and Fats & 308.25 & 0.08 \\
\hline 10. & Bahan Minuman /Beverages & 119.21 & 2.97 \\
\hline 11. & Bumbu-bumbuan / Spices & 2.09 & 0.06 \\
\hline 12. & Konsumsi lainnya / Miscellaneous & 106.61 & 2.00 \\
\hline 13. & $\begin{array}{l}\text { Makanan dan minuman jadi/ } \\
\text { Prepared food and beverages }\end{array}$ & 106.11 & 2.59 \\
\hline & $\begin{array}{r}\text { Total } \\
\end{array}$ & $2,400.25$ & 73.47 \\
\hline
\end{tabular}

Sumber : Data Primer Diolah, 2012/ Sources : Primary Data Processed, 2012

Tabel 6. Sebaran Ketahanan Pangan Rumah Tangga Responden Pembudidaya di Desa Sumur Gintung, Kabupaten Subang, Tahun 2012.

Table 6. Distribution of Fish Farmer Household Based on Food Security Categories at Sumur Gintung Village, Subang, 2012.

\begin{tabular}{lcc}
\hline \multicolumn{1}{c}{ Kategori/Category } & $\begin{array}{c}\text { Jumlah Responden/ } \\
\text { Number of Respondents }\end{array}$ & $\begin{array}{c}\text { Persentase/ } \\
\text { Percentages (\%) }\end{array}$ \\
\hline Tahan Pangan / Food Security & 0 & 0 \\
Rentan Pangan / Food Vulnerable & 18 & 47.37 \\
Kurang Pangan / Food Scarcity & 0 & 0 \\
Rawan Pangan / Food Insecurity & 20 & 52.63 \\
\hline \multicolumn{1}{c}{ Jumlah / Total } & 38 & 100 \\
\hline
\end{tabular}

Sumber : Data Primer Diolah, 2012/ Sources : Primary Data Processed, 2012 
mencapai ketahanan pangan. Pendapatan yang meningkat disertai dengan pengetahuan tentang gizi, diharapkan dapat menjadikan kelompok rumah tangga ini mencapai tahan pangan.

Pada Tabel 7 dapat dilihat hubungan antara pendapatan rumah tangga, proporsi pangan, angka kecukupan energi dan kategori ketahanan pangan. Responden yang termasuk ke dalam kategori kurang pangan memiliki jumlah yang paling banyak yakni sekitar 42,11\%; dan yang tahan pangan sebesar $34,21 \%$. Hal yang paling mendasar dari kategori ini adalah proporsi pengeluaran pangan yang kurang dari $60 \%$.

\section{Tingkat Kemiskinan pada Rumah Tangga Pembudidaya}

$\begin{array}{rrr}\text { Kondisi } & \text { kemiskinan rumah tangga } \\ \text { pembudidaya } & \text { berdasarkan }\end{array}$ karakteristik rumah tangga yang dikembangkan oleh BPS dengan menggunakan 14 indikator menunjukkan bahwa kepemilikan luasan rumah lebih dari $8 \mathrm{~m}^{2}$ dengan lantai yang berjenis keramik serta dinding berbahan baku tembok. Menurut Akhmadi et al. (2006), hal ini menunjukkan bahwa rumah tangga pembudidaya tergolong sejahtera.

Berdasarkan hasil kajian, diketahui bahwa semua responden pembudidaya sudah memiliki MCK sendiri. Hal ini menunjukkan bahwa rumah tangga pembudidaya sudah mengikuti perilaku hidup sehat. Air bersih yang digunakan untuk kegiatan sehari-hari masyarakat berasal dari sumur bor dan merupakan milik pribadi, sedangkan untuk minum menggunakan air isi ulang. Hal ini menunjukkan bahwa masyarakat sudah mengerti dan peduli akan arti kesehatan.

Bahan bakar yang digunakan rumah tangga pembudidaya untuk memasak adalah gas. Ukuran gas yang digunakan masyarakat adalah ukuran $3 \mathrm{~kg}$. Menurut masyarakat harga gas tersebut lebih terjangkau dibandingkan gas ukuran $12 \mathrm{~kg}$. Jika dilihat dari frekuensi mengkonsumsi daging/ ayam/ikan, berdasarkan hasil survey di lapangan frekuensi masyarakat yang mengkonsumsi makanan tersebut dua kali per minggu sampai lebih dari dua kali per minggu. Sedangkan untuk belanja pakaian, sebagian besar masyarakat berbelanja pakaian lebih dari satu kali dalam setahun. Belanja pakaian tidak hanya dilakukan pada saat hari besar atau hari raya saja. Hal ini menunjukkan bahwa sebagian besar pendapatan yang diperoleh digunakan untuk kebutuhan non pangan. Berdasarkan hasil survey diketahui bahwa rata-rata pembudidaya makan sebanyak 2 - 3 kali per hari sehingga kebutuhan akan makan sudah terpenuhi dengan baik. Jika dilihat dari kemampuan berobat, rata-rata pembudidaya mampu untuk berobat baik ke rumah sakit maupun ke dokter.

Berdasarkan hasil perhitungan dengan menggunakan pendekatan karakteristik rumah tangga diketahui bahwa secara umum tidak ada rumah tangga yang termasuk ke dalam kategori

Tabel 7. Hubungan Antara Pendapatan Rumah Tangga, Proporsi Pangan, Angka Kecukupan Energi dan Kategori Ketahanan Pangan.

Table 7. Relation Among Household Income, Food Proportion, Energy Sufficiency Level, and Food Security Categories.

\begin{tabular}{|c|c|c|c|c|c|c|}
\hline No & $\begin{array}{c}\text { Pendapatan } \\
\text { Rumah Tangga/ } \\
\text { Household Income } \\
\text { (Rp/Cap/Month) }\end{array}$ & $\begin{array}{c}\text { Pengeluaran } \\
\text { Pangan/ } \\
\text { Food } \\
\text { Expenditure } \\
\text { (Rp/Cap/month) }\end{array}$ & $\begin{array}{c}\% \\
\text { Pangan/ } \\
\text { Food }\end{array}$ & $\begin{array}{c}\% \\
\text { Angka } \\
\text { Kecukupan } \\
\text { Energi/ } \\
\text { Energy } \\
\text { Sufficiency } \\
\text { (AKE) }\end{array}$ & $\begin{array}{c}\% \\
\text { Responden/ } \\
\text { Respondent }\end{array}$ & $\begin{array}{l}\text { Kategori } \\
\text { Ketahanan } \\
\text { Pangan/ } \\
\text { Food Security } \\
\text { Category }\end{array}$ \\
\hline 1 & $1,175,260$ & 392,844 & 37 & 141 & 34.21 & $\begin{array}{l}\text { Tahan Pangan/ } \\
\text { Food Security }\end{array}$ \\
\hline 2 & $1,019,612$ & 691,970 & 68 & 160 & 10.53 & $\begin{array}{c}\text { Rentan } \\
\text { Pangan/ Food } \\
\text { Vulnerable }\end{array}$ \\
\hline 3 & 929,970 & 404,705 & 46 & 42 & 42.11 & $\begin{array}{l}\text { Kurang Pangan/ } \\
\text { Food Scarcity }\end{array}$ \\
\hline 4 & 381,940 & 294,557 & 76 & 39 & 13.16 & $\begin{array}{l}\text { Rawan Pangan/ } \\
\text { Food Insecurity }\end{array}$ \\
\hline
\end{tabular}

Sumber : Data Primer Diolah, 2012/ Sources : Primary Data Processed, 2012 
sangat miskin dan miskin. Sebanyak $63,2 \%$ rumah tangga pembudidaya masuk dalam kategori sejahtera. Kondisi ini sesuai dengan situasi di lapangan, dimana sebagian besar responden memiliki rumah yang luas, memiliki sarana MCK pribadi, fasilitas listrik dan lain sebagainya.

Pada Tabel 9 menggambarkan hubungan antara pendapatan rumah tangga, pengeluaran pangan, non pangan dan kategori kemiskinan. Suatu rumah tangga dikatakan sejahtera jika pengeluaran non pangannya lebih tinggi dibandingkan dengan pengeluaran pangannya. Hal ini sesuai yang dinyatakan oleh Rahman (2001) bahwa struktur pengeluaran dan konsumsi merupakan salah satu indikator untuk melihat kesejahteraan dan rumah tangga dengan pangsa pengeluaran pangan tinggi menunjukan tingkat kesejahteraan yang relatif lebih rendah dibandingkan dengan pengeluaran non pangan tinggi.

Rumah tangga yang memiliki pendapatan per kapita rata-rata per bulan Rp. 718.295 dan proporsi pengeluaran pangannya sebesar $64 \%$ termasuk ke dalam rumah tangga yang kurang sejahtera dimana ada sebanyak 52,63\% responden. Sedangkan rumah tangga yang termasuk sejahtera ada sebanyak $47,37 \%$ dengan pendapatan rata-rata sebesar Rp.1.210.009 dan proporsi pengeluaran pangan sebesar 33\%.Kategori kemiskinan juga dapat dilihat dari garis kemiskinan dimana batas garis kemiskinan menurut BPS adalah pendapatan per kapita sebesar Rp. 271.626. Sehingga berdasarkan hasil analisis diperoleh informasi bahwa rumah tangga yang termasuk miskin hanya sebesar $5,26 \%$ sedangkan yang termasuk tidak miskin sebesar 94,74\%.

Tabel 8. Persentase Tingkat Kemiskinan pada Rumah Tangga Pembudidaya Berdasarkan Karakteristik Rumah Tangga di Desa Sumur Gintung, Kabupaten Subang, Tahun 2012.

Table 8. Fish Farmer Household Percentage Based on Poverty Level Characteristic at Sumur Gintung Village, Subang, 2012.

\begin{tabular}{cccc}
\hline $\begin{array}{c}\text { Kelas/ } \\
\text { Class }\end{array}$ & $\begin{array}{c}\text { Rentang Nilai/ } \\
\text { Range of Value }\end{array}$ & $\begin{array}{c}\text { Tingkat Kemiskinan/ } \\
\text { The Poverty Level }\end{array}$ & $\begin{array}{c}\text { Persentase/ } \\
\text { Percentages (\%) }\end{array}$ \\
\hline I & $0.00-0.25$ & Sangat miskin/ Very Poor & - \\
II & $0.26-0.50$ & Miskin/ Poor & - \\
III & $0.51-0.75$ & Kurang Sejahtera/ Less Prosperous & 36.8 \\
IV & $0.76-1.00$ & Sejahtera/ Prosperous & 63.2 \\
\hline
\end{tabular}

Sumber : Data Primer Diolah, 2012 /Sources : Primary Data Processed, 2012

Tabel 9. Hubungan antara Pendapatan Rumah Tangga, Pengeluaran Pangan, Non Pangan dan Kategori Kemiskinan.

Table 9. Relation Among Household Income, Food Expenditure, and Poverty Categories.

\begin{tabular}{|c|c|c|c|c|c|c|c|}
\hline No & $\begin{array}{c}\text { Pendapatan } \\
\text { Rumah Tangga/ } \\
\text { Household } \\
\text { Income } \\
\text { (Rp/Cap/Month) }\end{array}$ & $\begin{array}{l}\text { Pengeluaran } \\
\text { Pangan/Food } \\
\text { Expediture } \\
\text { (Rp/Cap/ } \\
\text { month) }\end{array}$ & $\begin{array}{c}\% \\
\text { Pangan/ } \\
\text { Food }\end{array}$ & $\begin{array}{l}\text { Pengeluaran } \\
\text { Non Pangan/ } \\
\text { Non Food } \\
\text { Expenditure } \\
\text { (Rp/Cap/ } \\
\text { Month) }\end{array}$ & $\begin{array}{l}\% \\
\text { Non } \\
\text { Pangan/ } \\
\text { Non } \\
\text { Food }\end{array}$ & $\begin{array}{c}\% \\
\text { Responden/ } \\
\text { Respondent }\end{array}$ & $\begin{array}{c}\text { Kategori } \\
\text { Kemiskinan/ } \\
\text { Poverty } \\
\text { Categories }\end{array}$ \\
\hline 1 & 718,295 & 448,071 & 64 & 270,224 & 36 & 52.63 & $\begin{array}{c}\text { Kurang } \\
\text { Sejahtera/Less } \\
\text { prosperous }\end{array}$ \\
\hline 2 & $1,210,009$ & 381,194 & 33 & 828,814 & 67 & 47.37 & $\begin{array}{l}\text { Sejahtera/ } \\
\text { Prosperous }\end{array}$ \\
\hline 3 & 220,942 & 161,395 & 72 & 59,547 & 28 & 5.26 & Miskin/Poor \\
\hline 4 & 991,782 & 430,559 & 48 & 561,223 & 52 & 94.74 & $\begin{array}{l}\text { Tidak Miskin/ } \\
\text { Not poor }\end{array}$ \\
\hline
\end{tabular}

Keterangan/Notes:

1) Kurang Sejahtera(Less Prosperous) : Pangan (Food) $\geq$ Non Pangan (Non Food);

2) Sejahtera (Prosperous) : Pangan (Food) < Non Pangan (Non Food);

3) Miskin (Poor) : Income/Cap/Month < Rp 271.626,-; dan

4) Tidak Miskin (Not Poor) : Income/Cap/Month $\geq$ Rp 271.626,- 


\section{KESIMPULAN DAN IMPLIKASI KEBIJAKAN}

\section{Kesimpulan}

Hasil kajian menunjukkan bahwa besarnya rata-rata proporsi pengeluaran pangan terhadap total pengeluaran rumah tangga pembudidaya di Desa Sumur Gintung sebesar $44 \%$ dan proporsi pengeluaran non pangan terhadap total pengeluaran rumah tangga sebesar $56 \%$. Dimana pengeluaran pangan yang paling besar adalah untuk konsumsi tembakau (rokok) dan padi-padian (beras), sedangkan pengeluaran non pangan yang paling besar adalah untuk kelompok perumahan dan fasilitas rumah tangga (biaya rekening listrik, pulsa/telepon, gas, dan lain sebagainya).

Jika dilihat dari tingkatannya, kondisi ketahanan pangan rumah tangga pembudidaya termasuk dalam kategori rentan pangan sebesar $47,4 \%$ dan rawan pangan sebesar $53 \%$. Kondisi rawan pangan tersebut diduga karena pembudidaya dalam mengeluarkan pendapatannya kurang memperhatikan asupan gizi yang diperoleh dari makanan yang mereka konsumsi. Sedangkan jika dilihat dari tingkat kemiskinan pembudidaya berdasarkan pendekatan karakteristik rumah tangga dengan menggunakan 14 variabel menunjukkan bahwa rumah tangga pembudidaya berada pada kategori sejahtera sebesar $63,2 \%$ dan kurang sejahtera sebesar $36,8 \%$.

\section{Implikasi Kebijakan}

Berdasarkan hasil kajian tingkat pengeluaran konsumsi yang dilakukan terhadap pembudidaya ikan di Desa Sumur Gintung, Subang, pada umumnya mereka tergolong ke dalam keluarga sejahtera, namun bila dilihat dari asupan gizinya (kalori maupun protein) mereka termasuk keluarga yang rentan dan rawan pangan. Hal ini dapat disebabkan oleh:1) preferensi konsumsimasyarakat yang ada di lokasi; 2) kurangnya pengetahuan tentang bahan pangan yang bergizi tinggi; 3) terdapat pengaruh faktor sosial budaya tentang pantangan suatu makanan (misalnya makan ikan dapat menyebabkan cacingan); dan 4) kurang adanya variasi pangan yang dikonsumsi. Preferensi konsumsi pangan suatu individu dapat berbeda dengan individu lainnya (ada yang suka makan ikan dan ada pula yang sebaliknya). Preferensi ini dapat disebabkan oleh faktor kesehatan, usia, dan pendidikan.

Kebijakan yang ditawarkan untuk mengatasi kurangnya pengetahuan tentang bahan pangan yang bergizi tinggi, pengaruh budaya dan kurangnya variasi pangan dapat dilakukan melalui upaya sosialisasi secara periodik tentang peningkatan gizi masyarakat seperti gerakan makan ikan dan pelatihan/pendampingan pembudidaya untuk mengolah bahan pangan agar lebih bervariasi. Kegiatan sosialisasi tersebut bertujuan agar pembudidaya mendapatkan informasi yang bermanfaat terhadap pentingnya asupan gizi untuk pertumbuhan anak dan kesehatan anggota rumah tangga.

\section{DAFTAR PUSTAKA}

Akhmadi, D. S., Hastuti \& R. Fillaili. 2006. Verifikasi Ketepatan Sistem Pemantauan Kesejahteraan Oleh Masyarakat (SPKM) dalam Penargetan Keluarga Miskin : Hasil Verifikasi di Dua Desa Uji Coba SPKM. Laporan Lapangan SMERU. ISBN 978-9793872-30-8. Desember 2006. http://www. smeru.or.id/report/field/cbmsverification/ cbmsverification_ina.pdf. 49 hal.

Ariani, M. \& H. P. S. Rachman. 2003. Analisis Tingkat Ketahanan Pangan Rumah Tangga. Media Gizi dan Keluarga. Volume 27 No 2: $1-6$.

Badan Pusat Statistik (BPS). 2013. SUSENAS Buku 2: Konsumsi Kalori dan Protein Penduduk Indonesia dan Provinsi. Edisi September 2013. BPS. Jakarta.

2011. Pengeluaran Konsumsi Penduduk Indonesia 2011. BPS. Jakarta.

2010. Profil Kemiskinan Di Indonesia Maret 2010. Berita Resmi Statistik No. 45/07/Th. XIII, 1 Juli 2010. Jakarta.

2005. Analisis dan Perhitungan Tingkat Kemiskinan Tahun 2005. Jakarta. Badan Pusat Statistik.

Baliwati, Y. F. 2001. Model Evaluasi Ketahanan Pangan Rumah Tangga Petani : Desa Sukajadi, Kecamatan Ciomas, Kabupaten Bogor. Ringkasan Disertasi. Program Pascasarjana Institut Pertanian Bogor.

Chamdi, A. N. 2003. Kajian Profil Sosial Ekonomi Usaha Kambing di Kecamatan Kradenan, Kabupaten Grobongan. Prosiding Seminar Nasional Teknologi Peternakan dan Veteriner. Bogor, 29-30 September 2003. Puslitbang Peternakan. Bogor. HIm 312-317. 
Fauzi, A. 2007. Suatu Telaahan Masalah Kemiskinan di Indonesia. Makalah Jurusan Sosial Ekonomi Perikanan, Fakultas Perikanan dan IImu Kelautan, Institut Pertanian Bogor. Bogor.

Ilham, N. \& B. Sinaga. 2004. Penggunaan Pangsa Pengeluaran Pangan Sebagai Indikator Komposit Ketahanan Pangan. Pusat Analisis Sosial Ekonomi dan Kebijakan Pertanian Bogor. Bogor.

Irawan, P. B. 2000. Analisis Sensitivitas dan Pengukuran Kemiskinan. Fenomena Kemiskinan Sementara Selama Krisis Ekonomi di Indonesia. Widyakarya Nasional Pangan dan Gizi LIPI.

Kamaluddin, L. M. 1994. Strategi Penyiapan dan Kualitas SDM Pada Pembangunan Agribisnis Perikanan Indonesia. Makalah Seminar Sehari Himpunan Sosial Ekonomi Perikanan. IPB. Bogor.

Kartono, D., Hardinsyah, A. B. Jahari, A. Sulaeman \& M. Soekartri. 2012. Penyempurnaan Kecukupan Gizi Untuk Orang Indonesia. Widyakarya Nasional Pangan dan Gizi X. Jakarta. 20-21 November 2012. LIPI-Jakarta.

Maxwell, D., C. Levin, M. A. Klemeseau, M. Rull, S. Morris \& C. Aliadeke. 2000. Urban Livelihoods and Food Nutrition Security in Greater Accra, Ghana. IFPRI in Colaborative with Noguchi Memorial for Medical Research and World Health Organization. Research Report No.112. Washington, D.C.
Purwaningsih, Y., S. Hartono, Masyhuri \& J. H. Mulyo. 2010. Pola Pengeluaran Pangan Rumah Tangga Menurut Tingkat Ketahanan Pangan Di Provinsi Jawa Tengah. Jurnal Ekonomi Pembangunan Vol (2):236-253.

Purwantini, T. B. \& M. Ariani. 2008. Pola Konsumsi Pangan Pada Rumah Tangga Petani Padi. Seminar Nasional: Dinamika Pembangunan Pertanian dan Perdesaan; Tantangan dan Peluang Bagi Peningkatan Kesejahteraan Petani. Pusat Analisis Sosial Ekonomi dan Kebijakan Pertanian - Badan Litbang Pertanian. Bogor. 19 November 2008.

Rahman, H. P. S. 2001. "Kajian Pola Konsumsi dan Permintaan Pangan di Kawasan Timur Indonesia". Disertasi Program Pascasarjana. Institut Pertanian Bogor (IPB).

Saliem, P. \& E. Ariningsih. 2008. Perubahan Konsumsi dan Pengeluaran Rumah Tangga di Pedesaan: Analisis Data SUSENAS 1999-2005. Makalah Disampaikan Pada Seminar Nasional "Dinamika Pembangunan Pertanian dan Perdesaan". Bogor. Pusat Analisis Sosial Ekonomi dan Kebijakan Pertanian. 19 November 2008.

Sukiyono, K., I. Cahyadinata \& Sritoyo. 2008. Status Wanita dan Ketahanan Pangan Rumah Tangga Nelayan dan Petani Padi di Kabupaten Muko-Muko Provinsi Bengkulu. Jurnal Agro Ekonomi. 26:191-207.

Suryana, A. 2004. Ketahanan Pangan di Indonesia. Prosiding Widyakarya Nasional Pangan dan Gizi VIII. LIPI. Ketahanan Pangan dan Gizi di Era Otonomi Daerah dan Globalisasi. Jakarta. 